\title{
Interfaces
}

INTERFACES Image Texte Language

$41 \mid 2019$

Images / Memories

\section{Jules Feiffer and satire in words and images}

\section{Donald Friedman}

\section{(2) OpenEdition}

\section{Journals}

Electronic version

URL: http://journals.openedition.org/interfaces/654

DOI: $10.4000 /$ interfaces.654

ISSN: 2647-6754

\section{Publisher:}

Université de Bourgogne, Université de Paris, College of the Holy Cross

\section{Printed version}

Date of publication: 21 June 2019

Number of pages: $143-146$

ISSN: 1164-6225

\section{Electronic reference}

Donald Friedman, "Jules Feiffer and satire in words and images", Interfaces [Online], 41 | 2019, Online since 21 June 2019, connection on 07 January 2021. URL: http://journals.openedition.org/interfaces/ 654 ; DOI: https://doi.org/10.4000/interfaces.654

\section{(c) $\underset{\mathrm{BY}}{\mathrm{Y}}$}

Les contenus de la revue Interfaces sont mis à disposition selon les termes de la Licence Creative Commons Attribution 4.0 International. 


\title{
JULES FEIFFER AND SATIRE IN WORDS AND IMAGES
}

\author{
Donald Friedman
}

Jules Feiffer, born in 1929, is famous both as a cartoonist and playwright Donald Friedman recorded him circa 2002. Below are an introduction to the interview and a full transcript of the excerpts available at: https://www.youtube.com/watch?v=XSZP7C5spjY

\section{Introduction}

In the decades-long project that was the assembly and writing of The Writer's Brush, Paintings, Drawings, and Sculpture by Writers, I examined the lives and writings and artwork of hundreds of writer-artists. As any reader or contributor to Interfaces knows, the subject of the visual and literary, and the connections between image and text has endless aspects to it. There is also the equally fascinating matter of what impels the writer to attempt creative expression outside her customary discipline.

As for the larger question of what motivates any creative expression, there are all sorts of answers, from Divine inspiration to overcoming psyche-warping traumas. William Faulkner, himself an artist as well as writer, declared in a 1956 Paris Review interview: "The aim of every artist is to arrest motion which is life, by artificial means and hold it fixed so that 100 years later when a stranger looks at it, it moves again since it is life." Many of the writer-artists featured in The Writer's Brush claimed their urge to paint arose, not from any interest in achieving immortality, but simply from the pleasure they found in putting color on paper and canvas - a pleasure they did not find in their writing. Strindberg equated the sensation of painting to a hashish high.

Jules Feiffer's art, he says, is aimed at no less than the overthrow of the government. By this I've always taken him to mean undermining the corporate lock on our legislators, the lies and Orwellian double-speak of the government and the military, and not least, the thoughtless fashion and empty relationships of contemporary society. He was saying difficult things but he understood from the beginning that he had to simplify to be effective. "You don't overthrow the government by making the art difficult." The idea "is to take difficult things and make them seem simple so that the reader would 
not know what he or she was in for. You just dum-de-dum-de-dum-whack. And that's also not just politics and propaganda; that's also the fun in sleight of hand... If all this work would get done just for the educative purposes and I wasn't having a ball, the hell with it."

A playwright who's won New York Drama Critics and London Theater Critics awards, and two Obies, Feiffer is also a novelist, screenwriter, Academy Award-winning short filmmaker, children's book author and a Pulitzer Prize-winning cartoonist. He is also a warm, engaging, and open explainer of his own life. In this video you will learn not only about his creative process, how he interweaves text and image, but about the circumstances that informed his cynical and activist art-parents who were Jewish refugees from Poland and terrified to express themselves publicly, growing up as a high school nebbish who could only long after the beautiful girls.

\section{Transcript of Jules Feiffer's interview}

\section{The art of simplifying}

I understood that I was saying some very difficult stuff. That was the point of the whole thing : I'm doing this to overthrow the government. And you don't overthrow the government by making the art difficult. You don't overthrow the government by making the text weighted with too much dialogue. When I began, in the Cold War years, when there was very little dissent--certainly not in mainstream newspapers, and never - and not at all in comic strips, against the government, the Establishment, the Pentagon point of view, in that area as well as in others, where I was dealing with relationships, with men and women, with work and the sense of work, in all of these things, I had things I wanted to say that weren't being said generally. I learned how to simplify all of that from Beckett and Waiting for Godot. If you read Waiting for Godot, and just read ten pages of it, it reads like a comic strip. The art and the craft of this form was to take difficult things and make them seem simple, so that the reader would not know what he or she was in for. It was just dum-de-dum-de-dum, Whack! It's the old magician's sleight-of-hand. He gets you looking over here while doing this over there. And both as a cartoonist and as a playwright, I loved those stunts.

\section{Family origin and early years}

My mother was very supportive of me as a cartoonist, which was quite interesting, quite rare, because this was during the Depression. Cartoonists were not respectable creatures, and if she didn't believe in me, I wouldn't have been one because she was a tyrant, and she, you know, in her benign but 
heavy-handed fashion. And if she didn't want me to be a cartoonist, I wouldn't have been one. I would have been a dentist or anything she decided. She came out of Poland, as my father did, they beat the pogrom by fifteen minutes, and so she always expected another pogrom, and you were never secure in this country. And the thing you always did, as an American, was never to take advantage of being an American. My mother didn't believe in free speech on our part, because you could get into trouble. And when I went out there, I just did the opposite: I talked back.

Going through those high school years, to describe it mildly, all those years were feckless and fecked up, and I wanted to un-feck them, and the only way of doing that was, as countless numbers of writers and authors have found out over the years, is to address the social stupidity that happens to be you yourself - this rather embarrassing person, this poor excuse for a person - and create on paper something that was a lot better, or comment on something, or do something that would take you away from that, and turn you into something else. And in that translating process, as anybody discovers who went from average to becoming famous, that in the process, if you happen to get lucky and become famous, you, you work your way out of being that schmuck and suddenly you can talk to people, and people recognize you and admire you.

\section{Superman}

When Jerry Siegel died, The Times asked me to do a eulogy on him, and I wrote that the Superman myth came out of the rise of Hitler in Germany. Two Jewish boys living in Cleveland during the rise of American antisemitism, in the Bund movements and Father Coughlin on the radio, and geeky, nebbish, bespectacled pimply guys in high school looking at all these blond Nazi jocks getting the girls, you know, and getting the Lois Lanes. And here they were wandering around as a bunch of Clark Kents. And the Superman myth was a form of assimilation - merging Clark Kent with Superman as one character - that I'm not really this nerd, you know, if this girl, if this gorgeous girl who won't have anything to do with me, only knew that underneath, if I took my clothes off, I'd have this rippling muscle, this steroidal body, which of course they had pipestems, you know, but it's the fantasy, and I'd actually know how to talk to girls, I'd be witty, which I am not, I'd be this, which I am not. So it's that pure fantasy, instead of feeling like an alien from outer space, so the outer space that the real superhero came from was, as I wrote, not the planet Krypton, but the planet Minsk. 


\section{Writing and drawing}

The heft of my work, it came more out of written forms and all-time radio and maybe early television comedy, and it came more out of the Jack Benny Show, McGee and Molly. These works of the imagination, where you couldn't see anything but was still hysterically funny. Just about all of my work is written first. They are like improvised comedy that you start with an opening line, see where it goes, hope it goes somewhere. On rare occasions, when I come up blank and have a deadline, I might doodle something on paper hoping some character would speak to me, some pose. So I'd do somebody in a situation of stress hoping that he or she would start speaking to me and occasionally it did.

It's surprising that I started writing plays at such a late age - I was in my middle thirties - because I realize that I've always staged things and think of things as a page when I'm doing a cartoon, as a form of theatre or film, and that these are active, these characters I'm putting on paper. Just about all of my work - over forty years of cartoons - are people hardly moving at all. And when they did move, the movement is really a way of telling the reader what is really going on inside their heads. The drawing will often be the subtext behind the text. The text is saying something but the text is often the unreliable witness and the only truth you're going to pull out of this is what the character is doing with his or her body.

\section{Criticism vs creativity}

I think it's a danger in any art, and a danger we seem to engage in with great happiness and gusto these years, is to make every artist's work a little biography, and more than that, an extension of his problems, his or her neuroses. What does Walt Kelly being Irish have to do with Pogo? And why should we care? What seems to be too much of a pattern these days, in terms of scholarship, is the determination of the scholars and the critics to capture the essence of creativity, and by their treating it, treating creation like a crime that they have to solve, they become the creators and they achieve a status on par with whoever they're writing about. So the scholar who deconstructs F. Scott Fitzgerald and explains to you what Fitzgerald really meant then becomes his peer - no, he becomes his superior. And Fitzgerald didn't have a clue as to what he really was about, but this scholar, that scholar, the other scholar, being smarter, better educated, and more and a better student of Fitzgerald than Fitzgerald ever was is clearly more important in the canon than Fitzgerald. 